ISSN 1112-9867

http://www.jfas.info

\title{
EVALUATION OF PHYSICO-CHEMICAL PARAMETERS OF AGRICULTURAL SOILS IRRIGATED BY THE WATERS OF THE HYDROLIC BASIN OF SEBOU RIVER AND THEIR INFLUENCES ON THE TRANSFER OF TRACE ELEMENTS INTO SUGAR CROPS (THE CASE OF SUGAR CANE)
}

\author{
N. Benlkhoubi ${ }^{1}$, S. Saber ${ }^{1}$, A. Lebkiri ${ }^{1}$, El. Rifi ${ }^{1}$ and El. Fahime ${ }^{2, *}$ \\ ${ }^{1}$ Department of Chemical, Laboratory of Organic Synthesis and Extraction Processes, Faculty \\ of Science, University Ibn TOFAIL, BP 133, Kenitra, Morocco \\ ${ }^{2}$ UATRS - CNRST, Angle Allal Fassi / FAR, Hay Riad 10 000, \\ Rabat, Morocco
}

Received: 28 Jaunary 2016 / Accepted: 28 April 2016 / Published online: 01 May 2016

\begin{abstract}
This research was conducted in Kenitra (northwestern Morocco) to determine the physicochemical parameters and metallic concentrations at three levels: surface water of Sebou and Beht intended for irrigation, agricultural soils and sugarcane. The spectrometric analysis of source plasma emission (ICP) has identified eight trace elements contained in the materials taken from zone 1 ( $\mathrm{As}, \mathrm{Cd}, \mathrm{Co}, \mathrm{Zn}, \mathrm{Ni}, \mathrm{Pb}, \mathrm{Cu}$ and $\mathrm{Cr}$ ). The obtained results showed that the interaction between the different physicochemical parameters of agricultural soils decides the transfer of the metal elements to the plants. Indeed, for the soil which is used in this agriculture (for sugar cane), its irrigation water, and the contents of $\mathrm{Cr}, \mathrm{Cd}$ and $\mathrm{As}$ exceeds the accepted standards.
\end{abstract}

Keywords: heavy metals; ACP; sugar cane; agricultural soils; Oued Sebou; Oued Beht; Kenitra.

Author Correspondence, e-mail: nabilbenlk@mail.com doi: http://dx.doi.org/10.4314/jfas.v8i2.18 


\section{INTRODUCTION}

Moroccan agriculture has known a remarkable progress that has affected virtually all productions, whether animal or vegetable. The overall production has nearly tripled in real terms. Agriculture, despite the strong urbanization, still represents $15 \%$ of national wealth produced each year [1]. It is therefore absolutely essential to assess the risks related to the presence of heavy metals (trace elements) in the waters of irrigation, agricultural soils and crops since food is a major route of human exposure to trace elements [2].

The use of the waters of the river basin of Sebou area (Sebou Ouergha, Beht, low Sebou) for irrigation, which receives a load of $142 \mathrm{t} /$ year of metallic elements [3] coming from cottage industries and which is estimated by 2000 units [4], can generate a metal pollution drained along these rivers that will be transferred to the soil through irrigation waters and subsequently into the crops.

This work lists the physicochemical parameters of evaluation of agricultural soils in the city of Kenitra (Sidi Allal Tazi and Mograne) and the environmental impact induced by irrigation from a water pumping station coming from Sebou in the various environmental media including: the waters of irrigation, agricultural land and sugar cane.

\section{RESULTS AND DISCUSSION}

\subsection{Physico-chemical parameters of water and soil}

\section{a- physicochemical parameters of irrigation water}

The parameters of waters shown in Table 2 are below the national standards of irrigation water with the exception of Sodium.

The high sodium content is likely to be harmful to agricultural soils because it replaces the calcium and the magnesium adsorbed on the clay particles and causes the dispersion of soil particles. So, there is this burst of soil aggregates causing a hard and compact ground when it is dry and excessively waterproof [5]. The concentration of sodium in the irrigation water is estimated by the sodium absorption ratio (SAR). This ratio describes the amount of sodium in excess of the calcium and magnesium cations, that they can be tolerated in relatively large amounts of irrigation water in [5].

$$
\mathrm{SAR}=\mathrm{Na}+/ \sqrt{ }(\mathrm{Ca} 2++\mathrm{Mg} 2+) / 2
$$


Sodium, calcium, and magnesium are given in meq / 1 .

Concerning this study, irrigation waters were characterized by a RAS between 0 and 6 so that they can generally be used on any type of ground with little problems of sodium accumulation.

The water neutralization potency is attributed mainly to the presence of calcium and magnesium bicarbonates dissolved in water. The weakly basic $\mathrm{pH}$ of the analyzed irrigation water promotes the imprisonment of calcium and magnesium in this carbonate, making them unavailable to the plant medium [5].

Table 2. Physico-chemical parameters of irrigation waters

\begin{tabular}{cccccccccc}
\hline & \multicolumn{2}{c}{ Zone 1 } & \multicolumn{2}{c}{ Zone 2 } & \multicolumn{2}{c}{ Zone 3 } & \multicolumn{2}{c}{ Zone 4 } & Standard \\
Parameters & meq/l & mg /l & meq/l & mg / & meq/l & mg / & meq/l & mg / & $(\mathbf{m g} / \mathbf{l})$ \\
\hline pH & 7,95 & 7,95 & 7,22 & 7,22 & 7,76 & 7,76 & 7,91 & 7,91 & 6,5 à 8,4 \\
Electrical & 1,27 & 1,27 & 1,7 & 1,7 & 1,83 & 1,83 & 1,22 & 1,22 & 3 \\
conductivity & & & & & & & & & \\
(mmhos/cm) & & & & & & & & & \\
Calcium & 3,8 & 76 & 6,21 & 124,2 & 5,96 & 119,2 & 3,98 & 79,6 & - \\
Magnesium & 1,7 & 20,4 & 3,75 & 45 & 3,98 & 47,76 & 1,32 & 15,84 & - \\
Sodium & 7 & 161 & 7,35 & 169,05 & 8,50 & 195,5 & 7,20 & 165,6 & 69 \\
Potassium & 0,23 & 8,97 & 0,52 & 20,28 & 0,50 & 19,5 & 0,23 & 8,97 & - \\
Ammonium & 0,03 & 0,612 & 0,078 & 1,404 & 0,03 & 0,468 & 0,17 & 3,096 & - \\
Chlorides & 5,66 & 198,1 & 6,18 & 216,3 & 6,32 & 221,2 & 5,34 & 186,9 & 350 \\
Sulfates & 2,35 & 112,8 & 4,199 & 201,55 & 4,13 & 198,2 & 2,95 & 141,8 & 250 \\
Carbonates & - & - & - & - & - & - & - & - & - \\
Bicarbonate & 4,3 & 262,3 & 6,12 & 373,32 & 7,62 & 464,8 & 3,88 & 236,6 & 518 \\
Nitrate & 0,35 & 36,9 & 0,596 & 21,7 & 0,69 & 24,97 & 0,31 & 11,35 & - \\
\hline
\end{tabular}

\section{b- Physicochemical parameters of agricultural soils}

The results shown in Table 3 show that the particle size of the studied soils corresponds to a clay loam texture.

The studied soils are characterized by a slightly basic $\mathrm{pH}$, which moderately impedes the mineralization and dissolution of nutrients to make them available to plant roots and low organic content which requires the input of organic manure necessary for the photosynthesis 
of plants and the development of some micro-organisms necessary for the plant [6].

Table 3. Physico-chemical parameters of agricultural soils

\begin{tabular}{|c|c|c|c|c|}
\hline & Zone 1 & Zone 2 & Zone 3 & Zone 4 \\
\hline Fine ground \% & - & - & - & - \\
\hline Clay \% & 40,26 & 48,20 & 41,18 & 48,68 \\
\hline Fine silt \% & 31,02 & 27,95 & 35,64 & 28,73 \\
\hline Coarse silt \% & 16,46 & 16,98 & 22,26 & 25,03 \\
\hline Sandy $\%$ & 12,89 & 4,55 & 0,90 & 0,72 \\
\hline Coarse sand \% & 1,93 & 0,81 & 0,63 & 0,41 \\
\hline pH & 8,07 & 8,52 & 8,21 & 8,23 \\
\hline $\begin{array}{c}\text { Electrical conductivity } \\
\text { in the extract } 1 / 5 \\
(\mathrm{mmhos} / \mathrm{cm})\end{array}$ & 0,18 & 0,47 & 0,22 & 0,24 \\
\hline Limestone total \% & 19,40 & 15,20 & 16,60 & 15,20 \\
\hline Organic matter $(\%)$ & 1,25 & 2,10 & 1,67 & 2,10 \\
\hline Organic carbon \% & 0,72 & 1,22 & 0,97 & 1,22 \\
\hline $\begin{array}{c}\text { Ammonia nitrogen } \\
(\text { ppm) }\end{array}$ & 23,40 & 17,28 & 21,24 & 20,16 \\
\hline $\begin{array}{c}\text { Ammonia nitrogen } \\
(\text { ppm })\end{array}$ & 74,40 & 23,04 & 100,44 & 68,20 \\
\hline Mineral nitrogen (ppm) & 98,52 & 40,32 & 121,68 & 88,36 \\
\hline - Calcium (meq / 100) & 13,90 & 13,60 & 15,20 & 18,10 \\
\hline - Magnesium (meq/100) & 15,00 & 15,60 & 14,60 & 14,50 \\
\hline - Sodium (méq/100) & 1,00 & 3,75 & 1,58 & 1,83 \\
\hline - Potassium (méq/100) & 0,59 & 1,55 & 0,99 & 0,85 \\
\hline Are & 30,49 & 34,50 & 32,36 & 35,28 \\
\hline CEC & 30,50 & 35,50 & 32,50 & 35,50 \\
\hline $\begin{array}{l}\text { Available phosphorus } \\
\text { (ppm) }\end{array}$ & 50 & 33 & 49 & 14 \\
\hline $\begin{array}{c}\text { Potassium echangeble } \\
\text { (ppm) }\end{array}$ & 252 & 481 & 423 & 434 \\
\hline
\end{tabular}

Nitrogen $(\mathrm{N})$ is an element for living organisms, assimilated by plants mostly as nitrate (NO3) or ammonium (NH4 +) from the soil solution [6], is contained in the soil in the area 2 at low 
concentrations, which involves the contribution of nitrogen fertilizers.

In contrast, the concentration of assimilable phosphorus, which is a nutrient and necessary element for the growth of cultures in the zone 4 of soil, is less important compared to other areas.

Regarding the rest of the nutritious and the consitutive elements for plants, they are concentrated in the soil of all areas to tolerable and suitable levels for plant growth according to the interpretations of the ORMVAG.

\section{c- Influence of physicochemical parameters of the studied agricultural soils on the transfer of trace elements to the crops}

The physicochemical parameters affect the concentration of the metallic elements and decide their transfer from one environmental medium to another. Indeed, the weakly basic $\mathrm{pH}$ of irrigation water and alkali of the studied agricultural soils limit the mobility of metal and promotes their retention by the clay soil particles. Thus the clay structure for maintaining the metallic trace elements is carried out by adsorption in two modes [7]:

Adsorption by formating a covalent bond between the metal and the terminal - $\mathrm{OH}$ groups of the solid surface according to the following mechanism: X-O-H $+\mathrm{M}^{\mathrm{n}+} \rightarrow \mathrm{XO}-\mathrm{M}^{\mathrm{n}-1}+\mathrm{H}^{+}$.

Adsorption By exchanging ions based on the ionic substitution at the lamellar space of the clay. This mechanism depends on the load and the relative size of the exchanged metal elements. However, it is the second mode (adsorption at the solid surface) that predominates in the clay structure.

The values of cationic exchange capacity (CEC) vary between 30.5 and $35.5 \mathrm{meq} / 100 \mathrm{~g}$. These values are quite low compared to the average values reported by [8] (60 meq/100 g for mineral soil), following the low organic matter of the studied soils where the metal elements are less complex by the latter and more available for root crops. However, there was an increase of the cationic exchange capacity with an increase in $\mathrm{pH}$.

The rate of the total limestone soils in the different areas are average (15.2\% to $19.4 \%$ ). Limestone provides the plant with the necessary calcium. Among others, limestone blocks some elements which are indispensable to plants such as trace elements ( $\mathrm{Zn}$ and $\mathrm{Cu}$ ) [9].

2.2. Metallic fractions contained in the irrigation water, agricultural soil, bagasse and sugar cane juice (Zone 1) 
The metallic contents in the supports of zone 1 represented by Table 4 show concentrations that exceed the thresholds set by the Moroccan standard of irrigation water (As and Cd), the AFNOR standards (NFU 44-041) for agricultural soils ( $\mathrm{Cr}$ and $\mathrm{Cd}$ ) and the Codex Alimentarius standards for sugar cane juice (As).

Table 4. Results of nutrient trace elements in the irrigation water, agricultural soil, bagasse and sugar cane juice taken from Zone 1

\begin{tabular}{|c|c|c|c|c|}
\hline & $\begin{array}{c}\text { Irrigation } \\
\text { water (mg/l) }\end{array}$ & Standards & $\begin{array}{c}\text { Agricultural soils } \\
(\mathrm{mg} / \mathrm{kg})\end{array}$ & Standards \\
\hline As & 0,247 & 0,1 & 30,43 & - \\
\hline Cd & 0,042 & 0,01 & 10,6 & 2 \\
\hline Co & 0,034 & 0,5 & 19,75 & 30 \\
\hline $\mathrm{Cr}$ & 0,218 & 1 & 487,09 & 150 \\
\hline $\mathrm{Cu}$ & 0,117 & 2 & 48,66 & 100 \\
\hline $\mathbf{N i}$ & 0,132 & 2 & 41 & 50 \\
\hline $\mathbf{P b}$ & 0,296 & 5 & 13,19 & 100 \\
\hline \multirow[t]{2}{*}{$\mathbf{Z n}$} & 0,556 & 2 & 125,07 & 300 \\
\hline & $\begin{array}{l}\text { Bagasse } \\
(\mathrm{mg} / \mathrm{kg})\end{array}$ & $\begin{array}{l}\text { Standards } \\
\text { (EC } \\
\text { directive) }\end{array}$ & $\begin{array}{c}\text { Sugar cane juice } \\
(\mathrm{mg} / \mathrm{l})\end{array}$ & $\begin{array}{c}\text { Standards } \\
\text { Codex } \\
\text { Alimentarius }\end{array}$ \\
\hline As & $\leq \mathrm{LQ}$ & 4 & 0,495 & 0,2 \\
\hline Cd & 0,64 & 1 & 0,051 & - \\
\hline Co & 0,204 & - & 0,012 & - \\
\hline $\mathrm{Cr}$ & 1,034 & - & 0,236 & - \\
\hline $\mathbf{C u}$ & 4,19 & - & 0,274 & 5 \\
\hline $\mathbf{N i}$ & 3,591 & - & 0,208 & - \\
\hline $\mathbf{P b}$ & 1,619 & 10 & 0,142 & $0,2-0,3$ \\
\hline $\mathbf{Z n}$ & 7,075 & - & 0,711 & 5 \\
\hline
\end{tabular}

Only a small fraction of the total contents of metallic trace elements in soil is available for plant roots (More bass from 1 to 3 orders of magnitude) [10]. Indeed, the metal enrichment for sugar cane juice and bagasse is respected in the following descending order:

- Bagasse: $\mathrm{Zn}>\mathrm{Cu}>\mathrm{Ni}>\mathrm{Pb}>\mathrm{Cd}>\mathrm{Cr}>\mathrm{Co}>\mathrm{As}$.

- Sugarcane juice: $\mathrm{Zn}>\mathrm{As}>\mathrm{Cr} \mathrm{Ni} \sim \mathrm{Cu}>\mathrm{Pb}>\mathrm{Cd}>\mathrm{Co}$. 
Moreover, the passage from one organ to another of heavy metals is performed through the carriers that regulate the migration of the element through the chemical mechanisms (complexation with: organic acids, sugars, phenols and peptides and precipitation) that facilitate the movement or reduce it [11]. This explains the fluctuation in the range of metallic enrichment between sweet juice of the cane and bagasse.

\section{- Analyse globale des concentrations métalliques}

The global analysis by the method of PCA (principal component analysis) is combined with the different levels of trace elements in a limited number of factors in order to facilitate the detection of independence relations between different metal concentrations.

Figure 2 illustrates the degree of information (proper value \%) that each factor represents (number of compounds). Indeed, it is found that the first factor represents $99 \%$ of the overall total of the information of variables (As, $\mathrm{Cr}, \mathrm{Cd}, \mathrm{Co}, \mathrm{Cu}, \mathrm{Ni}, \mathrm{Pb}$ and $\mathrm{Zn}$ ) while the second factor represents $0.15 \%$ of variables. Therefore, the factor 1 and 2 , which restore $99.15 \%$ of the variable, will be adopted to explain the correlation between the various metal contents.

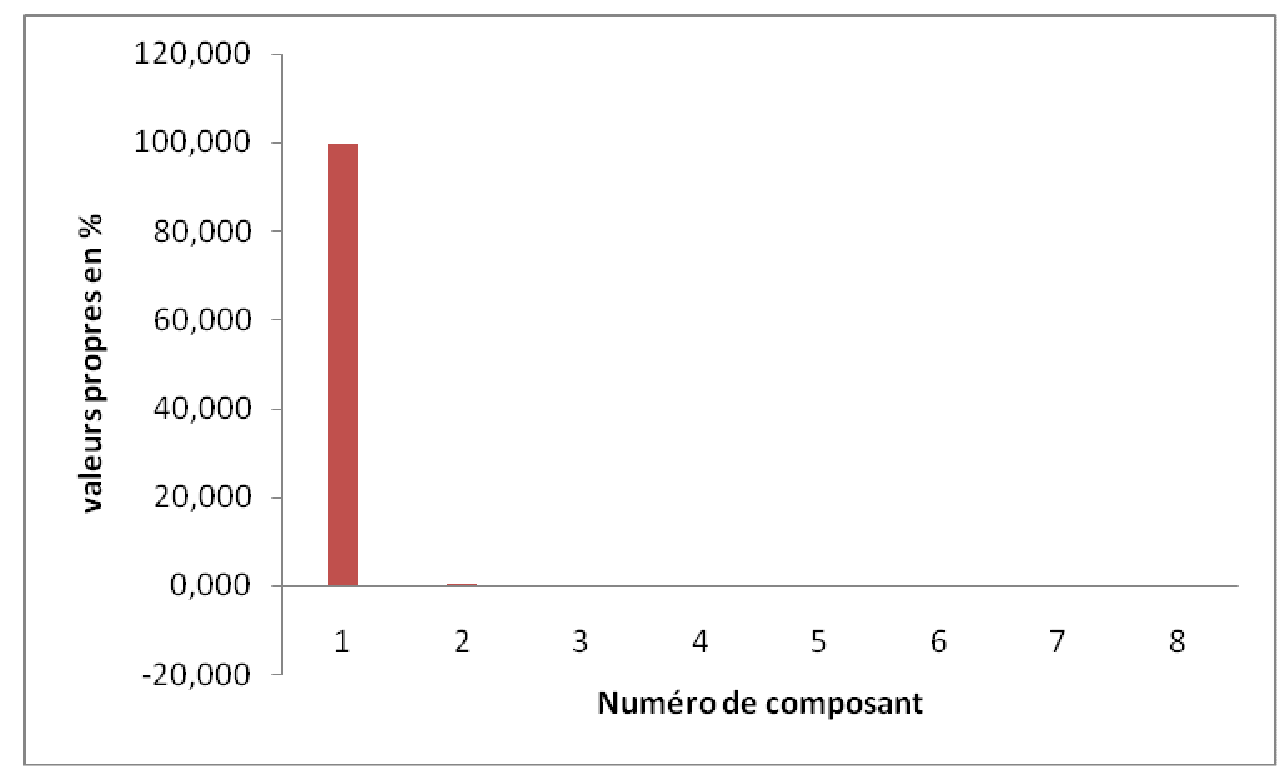

Fig.2. Diagram of the proper values of each component

The correlations on the axis of factors 1 and 2 (component 1 and component 2) are displayed on the factorial map after rotation (Fig.3). However, it is noted that all the metallic elements are positively correlated in both axes. Thus we have: 
- A high correlation of variables: $\mathrm{Zn}, \mathrm{Pb}, \mathrm{Cu}, \mathrm{Ni}$ and $\mathrm{Cd}$ on the axis 1 (correlation> 0.7)

- A good correlation of variables: As, $\mathrm{Cr}$ and $\mathrm{Co}$ on axis 2 (correlation> 0.7).

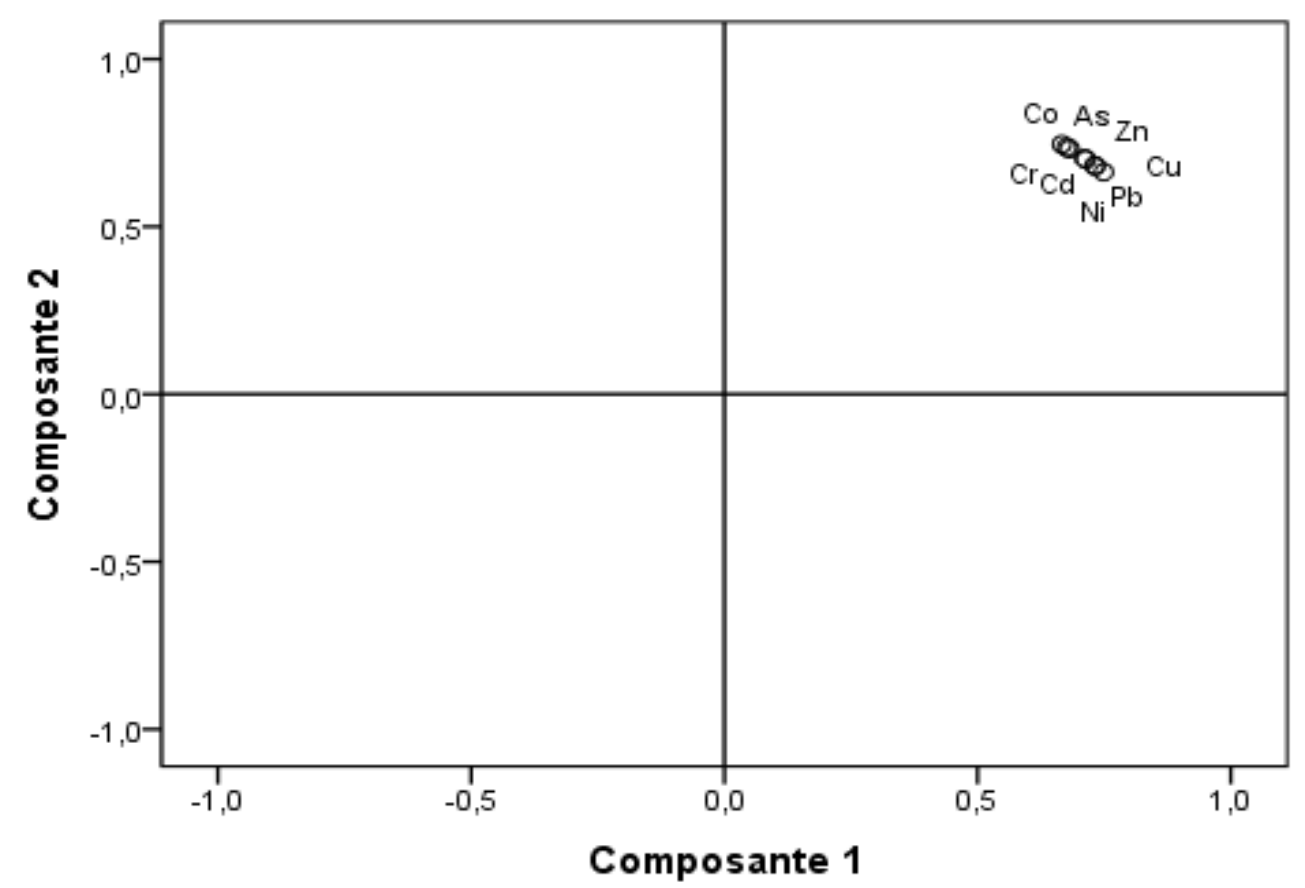

Fig.3. Correlation of metallic trace elements on the axes of Component 1 and Component 2 Where the factor 1 includes more and more variables $(\mathrm{Zn}, \mathrm{Cu}, \mathrm{Ni}, \mathrm{Pb}, \mathrm{Cd})$ which are strongly accumulated in the bagasse with respect to $\mathrm{Co}, \mathrm{Cr}$ and As, compiled by the factor 2 . Thus, for the metallic elements of the factor 1 which restores $99 \%$ of the variable, the increase in the content of a metal induces an increase of the other in all the combined supports.

\section{EXPERIMENTAL}

\subsection{Areas of Study}

Surface water for irrigation in the region of Gharb-Chrarda-Beni Hssen (northwestern Morocco) consists mainly of the hydraulic basin of Sebou and its tributaries. The areas of study which are part of the complaint of Gharb, are two rural towns are named Sidi Allal Tazi and Mogran belonging to the city of KENITRA. These areas that develop various crops including cereals, fodder and sugar crops have pumping stations of irrigation waters of the Oued Sebou installed on and Oued Beht under the direction of the Regional Office of Setting Agricultural Value of Gharb (ORMVAG). 
The agricultural lands Irrigated by the pumping stations of irrigation waters of Sebou and Beht (Fig.1) were identified through the pipes that supply their hydraulic needs.

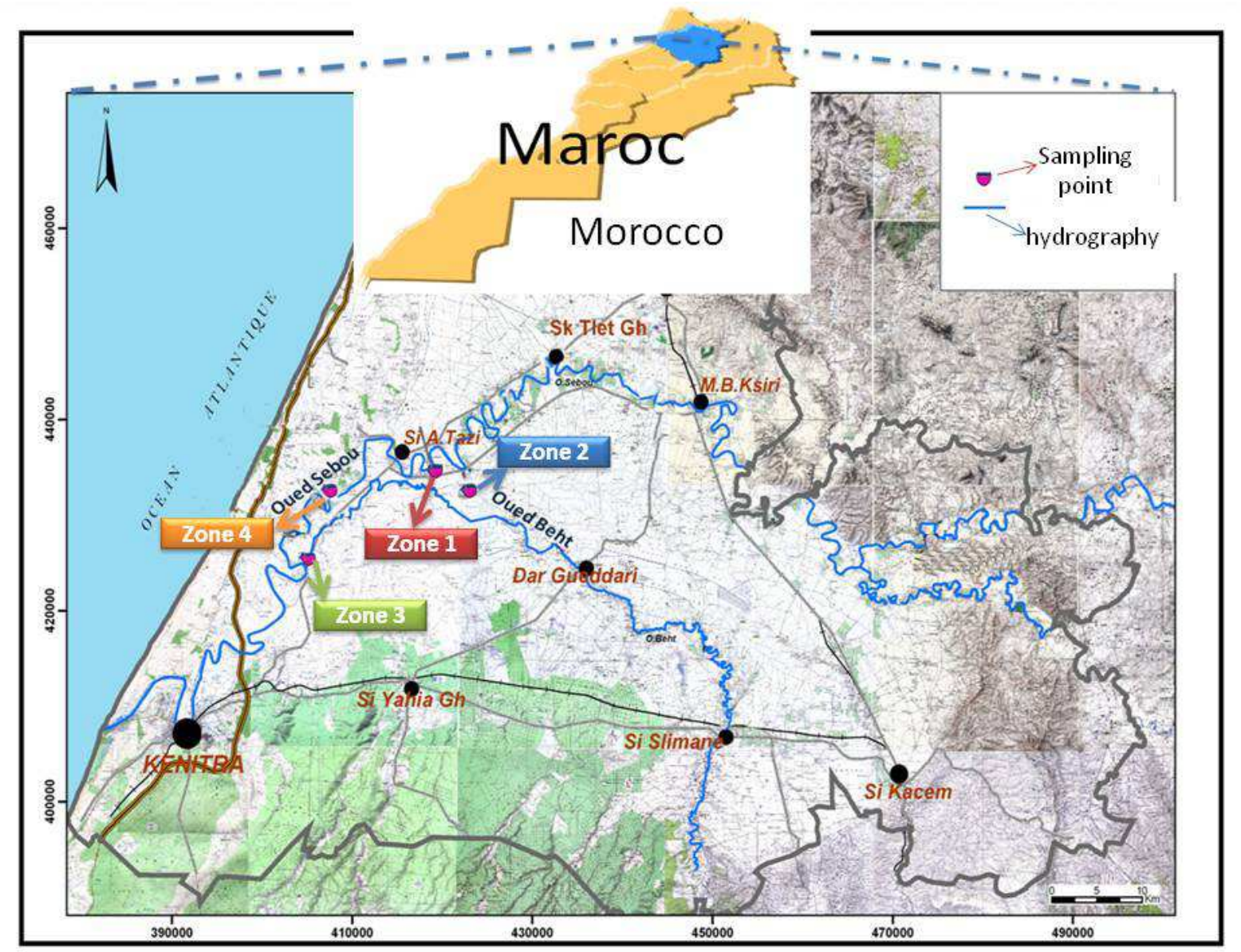

Fig.4. Location of the study areas of Oued Sebou and Oued Beht

Agricultural areas, which are located through topographic coordinates of the four pumping stations of surface water coming from Oued Sebou and Oued Beht (Table 5), are located at 27 $\mathrm{Km}$ (Mograne rural commune) and $44 \mathrm{Km}$ (rural commune of Sidi Allal Tazi) of the province of Kenitra. Thus, two surfaces were selected in each rural district:

- Zone 1: Agricultural area irrigated by pumping station of Sebou surface water at Sidi Allal Tazi.

- Zone 2: Agricultural area irrigated by a pumping station developed at a channel for diverting the flow of water of the Oued Beht to meet the needs of farmers in irrigation of their crops at Sidi Allal Tazi.

- Zone 3: Agricultural area irrigated by pumping station of Beht surface water at Mograne. 
- Zone 4: Agricultural area located at Mograne and irrigated by the water of the dam that has the function of limiting losses in the sea waters of SEBOU river and maintenance of the water that will serve as a source of hydraulic irrigation.

Table 5. Topographic coordinates of sampling sites

\begin{tabular}{ccc}
\hline Zones & Latitude $(\mathbf{N})$ & Longitude $(\mathbf{W})$ \\
\hline Zone 1 & $34^{\circ} 30^{\circ} 22^{\prime \prime}$ & $6^{\circ} 17^{`} 13^{\prime \prime}$ \\
Zone 2 & $34^{\circ} 29^{\prime} 37^{\prime \prime}$ & $6^{\circ} 14^{\circ} 04^{\prime \prime}$ \\
Zone 3 & $34^{\circ} 24^{\prime} 36^{\prime \prime}$ & $6^{\circ} 25^{\prime} 48^{\prime \prime}$ \\
Zone 4 & $34^{\circ} 28^{\prime} 59^{\prime \prime}$ & $6^{\circ} 24^{\prime} 08^{\prime \prime}$ \\
\hline
\end{tabular}

\subsection{The used materials}

The samples were taken on 04/20/2014, which is the harvest period of sugarcane.

\section{a- Sampling of irrigation water}

Irrigation water were removed from the pumping stations in polyethylene sterile bottles of $500 \mathrm{ml}$ and rinsed beforehand with the sample before being transported to the laboratory and stored at $4{ }^{\circ} \mathrm{C}$.

\section{b- Sampling of agricultural soils}

The soil was taken in a zigzag way from five points on average of each site using a helical auger. The soils (Layer: 0-15 cm) from the same area were mixed, put into a clean plastic bag and labeled for transport to the laboratory.

\section{c- Sugarcane Sampling}

The sugar canes collected from the five points of zone 1 were put into a clean plastic bag and labeled to be sent to the laboratory where they were washed with tap water and then rinsed by distilled water to remove dirt and dust.

\section{d- Extraction of sugar cane juice}

The sugar cane juice was obtained by grinding the rods in a press comprising two rollers which provide the crushing allowing the recovery of juice (sugar juice) and bagasse (fibrous residue of sugarcane).

\subsection{Treatment of samples and methods of analysis}

\section{a- mineralization of irrigation water and sugarcane juice [12]}

A $10 \mathrm{ml}$ sample of water was taken up in $10 \mathrm{ml}$ of $50 \%$ hydrofluoric acid and dried with a sand bath in a Teflon beaker. Dissolving the obtained residue was effected by adding $7.5 \mathrm{ml}$ of 
hydrochloric acid and $2.5 \mathrm{ml}$ of nitric acid. The beaker was covered with a watch glass and placed on a hotplate until the disappearance of red vapors synonymously with a complete mineralization. The solution obtained after filtration was completed to $50 \mathrm{ml}$ with distilled water.

\section{b- Mineralization of soil [13]}

An amount of $1 \mathrm{~g}$ of the soil of the same depth was sieved by a sieve of $1 \mathrm{~mm}$ and dried at $70^{\circ} \mathrm{C}$ for 48 hours and was calcined in a muffle furnace at $450^{\circ} \mathrm{C}$ for 2 hours. The sample was then taken up in $10 \mathrm{ml}$ of $50 \%$ hydrofluoric acid to be dried again in a Teflon beaker on a sand bath. The dissolving the residue is performed by a mixture of hydrochloric and nitric acid $(7.5$ and $2.5 \mathrm{~mL})$. The suspension of the solution obtained after the filtration was completed to $50 \mathrm{ml}$ with distilled water.

\section{c- Mineralization of plant material [12]}

A test sample of 1 to $2 \mathrm{~g}$ of vegetable, dried at $70^{\circ} \mathrm{C}$ for 48 hours and then crushed, was calcined in a muffle furnace at $450^{\circ} \mathrm{C}$ for 4 hours. The obtained ash was mineralized by aqua regia ( $\mathrm{HNO} 325 \%$ and $75 \% \mathrm{HCl}$ ) then reduced to dryness on a sand bath until the discoloration of the solution. The resulting residue was solved in $10 \mathrm{ml}$ of $\mathrm{HCl}(5 \%)$, then filtered to 0.45 microns, before being diluted with $\mathrm{HCl}(5 \%)$ to the final volume of $20 \mathrm{ml}$.

\section{d- The physicochemical analysis and the determination of trace metals}

The analyzes of the physico-chemical parameters of soil and irrigation water were conducted in the laboratory of ORMVAG and the determination of metal fractions (Chromium, Cobalt, Copper, Zinc, Arsenic, Lead, Cadmium and Nickel ) developed at the media, were read in ICP-AES (Ultima 2) by the National Scientific and Technical Research Centre (Rabat). The analytical laboratory uses the standards (1000 ppm precise Jobin Yvon) which are certified by ISO 9001 quality assurance system.

The metal concentrations conversion formula of $\mathrm{mg} / \mathrm{l}$ to $\mathrm{mg} / \mathrm{kg}$ for solid supports is as flows:

Cech $(\mathrm{mg} / \mathrm{kg})=$ Cech $(\mathrm{mg} / \mathrm{l}) *$ VMineralization $(\mathrm{l}) /$ Mass sec taking $(\mathrm{kg})$

With Cech $(\mathrm{mg} / \mathrm{kg})$ the metal final concentration in $\mathrm{mg} / \mathrm{kg}$, Cech $(\mathrm{mg} / \mathrm{l})$ the metal concentration in $\mathrm{mg} / \mathrm{l}$, Vmineralization the volume of the sample after the mineralization in $\mathrm{L}$ and Mass sec prise d'essai $(\mathrm{kg})$ the mass of the dried sample before calcinations in $\mathrm{kg}$.

The principal component analysis of the average heavy metal content of irrigation water, 
agricultural lands and sugar cane was produced by IBM SPSS STATISTICS software according to the procedure published by several authors $[14,15]$.

\section{CONCLUSION}

In this study, we studied the influence of the physicochemical parameters of agricultural soils irrigated by the waters of the Sebou hydraulic basin on the transfer of metals to crops and the bioaccumulation of trace elements in sugar cane sown in the ground of Zone 1.

Indeed, the weakly basic $\mathrm{pH}$ of the irrigation water and the clay texture of soil particles inhibit the bioavailability of heavy metals to the crop roots. This limited mobility following the physicochemical factors can be mitigated by the physiology of the plant. The nature of culture and the chemical form of this metal in the soil solution can be favorably absorbed by plant roots.

On zone 1 , the average concentrations of $\mathrm{As}$ and $\mathrm{Cd}$ in irrigation waters are above the standards required by the national norms of waters intended for irrigation. In contrast, the average contents of $\mathrm{Cr}$ and $\mathrm{Cd}$ in agricultural soils exceed the limits recommended by the French standard AFNOR. Regarding plant supports, the As in the sugar cane juice exceeds the levels recommended by the Codex Alimentarius Standard.

Furthermore, the bagasse is able to accumulate the divalent ions (trace elements) in the following descending order: $\mathrm{Zn}>\mathrm{Cu}>\mathrm{Ni}>\mathrm{Pb}>\mathrm{Cd}>\mathrm{Cr}>\mathrm{Co}>\mathrm{As}$.

For the global analysis (PCA), the correlation between the different metals is positive in both the developed axes, so the contents of trace elements in all supports are proportional to each other.

\section{ACKNOWLEDGEMENTS}

This research was supported by the grant of Laboratory Team Organic Synthesis and Extraction Processes, Faculty of Science, University Ibn Tofail, BP 133 Kenitra 14000, Morocco.

\section{REFERENCES}

[1] HCP, Agriculture 2030 Quels avenirs pour le Maroc. Haut Commissariat au Plan 
Royaume du Maroc, 2004, pp. 4.

[2] Benedetto, D, Méthodes spectroscopiques d'Analyse et Caractérisation des Métaux Lourds, Ecole des Mines de Saint-Etienne, 1997, pp. 11.

[3] ONEM, Stratégie Nationale pour la Protection de l'Environnement et le Développement Durable, Observatoire National de l'Environnement du Maroc, 1995, pp. 127.

[4] A.B.H.S, Etude stratégique d'intervention de l'A.B.H. Atelier de concertation du 9 septembre 2004. Agence du Bassin Hydraulique du Sebou, 2004, pp. 45.

[5] Couture, I. and M. Montérégie-Est. Analyse d'eau pour fin d'irrigation. Agri-Vision., 2004: 2-5.

[6] Genot, V., G. Colinet, and L. BOCK. La fertilité et la biodiversité dans les sols. Partim Biodiversité., 2007: 3.

[7] Éléments traces métalliques - Guide méthodologique. Recommandations pour la modélisation des transferts des éléments traces métalliques dans les sols et les eaux souterraines, Ministère de L'écologie, Du Développement Durable et de L'énergie, France, 2008.

[8] Alloway, B.J., Soil processes and the behaviour of heavy metals. In Alloway, B. J. (Ed.). Heavy metals in soils. Chapman \& London., 1995: 11-35.

[9] Rattan, R.K., et al., Long-term impact of irrigation with sewage effluents on heavy metal content in soils, crops and groundwater-a cause study. J. Agri. Ecosystems and Environ., 2005, (109): 310-322.

[10] Bargagli, R., Trace elements in terrestrial plants. An ecophysiological approach to biomonitoring and biorecovery. Springer., 1998: 324

[11] Cataldo, D.A., R.E. Wildung, and T.R. Garland, Speciation of Trace Inorganic Contaminants and Bioavailability to Animals: An Overview. J. Environ. Qual., 1987: 289-295. [12]Tauin, C. and C. Juste, Effet de l'application à long terme de diverses matières fertilisantes sur l'enrichissement en métaux lourds des parcelles, Rapport du contrat 4084/93. Ministère de l'environnement, France., 1986

[13]AFNOR, Norme Française X 31-151 Méthode de minéralisation des boues et des sols, 1984, pp. 17.

[14]Blidi, S.E., et al., Contamination des rizières de la plaine du Gharb (Maroc) par des 
métaux traces. Vecteur Environnement., 2006: 46-53.

[15]Bouchouata, O., et al., Bioaccumulation des métaux lourds par les cultures maraîchères au niveau du Bassin de Sebou (Maroc). Bulletin de l'Institut Scientifique, Rabat, section Sciences de la Vie., 2012: 189-203.

\section{How to cite this article:}

Benlkhoubi N, Saber S, Lebkiri A, Rifi El and Fahime El. Evaluation of physico-chemical parameters of agricultural soils irrigated by the waters of the hydrolic basin of Sebou river and their influences on the transfer of trace elements into sugar crops (the case of sugar cane). J. Fundam. Appl. Sci., 2016, 8(2), 438-451. 